\title{
PENGARUH PENDEKATAN VISUAL THINKING TERHADAP KEMAMPUAN KONEKSI MATEMATIS SISWA
}

\author{
Erdawati Nurdin ${ }^{1}$, Hayatun Nufus ${ }^{2}$, Hasanuddin ${ }^{3}$ \\ ${ }^{1}$ Universitas Islam Negeri Sultan Syarif Kasim \\ erdawati.nurdin@uin-suska.ac.id \\ ${ }^{2}$ Universitas Islam Negeri Sultan Syarif Kasim \\ hayatunnufus@uin-suska.ac.id \\ ${ }^{3}$ Universitas Islam Negeri Sultan Syarif Kasim \\ hasanuddin@uin-suska.ac.id
}

\begin{abstract}
ABSTRAK
Penelitian ini bertujuan untuk melihat pengaruh pendekatan visual thinking terhadap peningkatan kemampuan koneksi matematis siswa. Penelitian ini merupakan penelitian kuasi eksperimen dengan desain penelitian noneqivalent control group design. Sampel pada penelitian ini adalah siswa kelas VIII Madrasah Tsanawiyah yang dipilih melalui teknik purposive sampling. Instrumen penelitian yang digunakan adalah soal tes kemampuan koneksi matematis dan lembar observasi. Hasil observasi menunjukkan peningkatan aktivitas siswa dan guru di setiap pertemuan pada kelas yang memperoleh pembelajaran dengan pendekatan visual thinking. Data peningkatan kemampuan koneksi yang diperoleh tidak berdistribusi normal, sehingga analisis data dilakukan menggunakan uji nonparametrik U Mann Whitney. Dari analisis data diperoleh kesimpulan bahwa tidak terdapat pengaruh yang signifikan pembelajaran dengan pendekatan visual thinking terhadap peningkatan kemampuan koneksi matematis.
\end{abstract}

Kata Kunci: Gain Ternormalisasi, Koneksi Matematis, Visual Thinking.

\begin{abstract}
This study aims to see the effect of visual thinking approach on improving students' mathematical connection ability. This is a quasi-experimental research with nonequivalent control group design. The sample is students on class VIII in Madrasah Tsanawiyah which is chosen by using purposive sampling technique. The research instruments used are a test of mathematical connection ability and an observation sheet. The results of the observations showed an increase in the activity of students and teachers in each meeting in the classroom that obtained learning by using visual thinking approach. The data of increased connection ability is not normally distributed, so the data analysis is done using U non-parametric test of Mann Whitney. From the data analysis, it can be concluded that there is no significant effect of learning by using visual thinking approach to students' mathematical connection ability improvement.
\end{abstract}

Keywords: Normalized Gain, Mathematical Connection, Visual Thinking. 
Format Sitasi: Nurdin, E., Nufus, H., \& Hasanuddin. (2018). Pengaruh Pendekatan Visual Thinking Terhadap Kemampuan Koneksi Matematis Siswa. KALAMATIKA Jurnal Pendidikan Matematika, $3(1), 17-26$.

Penyerahan Naskah: 27 Desember 2016 || Revisi: 28 Februari 2018 || Diterima: 28 Februari 2018

\section{PENDAHULUAN}

Berdasarkan hasil survei yang dilakukan oleh Programme for International Student Assesment (PISA) pada tahun 2015 menggambarkan lemahnya kemampuan matematis pelajar Indonesia yang berusia 15 tahun. Prestasi belajar matematika siswa di Indonesia berada pada urutan ke 64 dari 72 negara yang menggikuti survei tersebut, dengan nilai rata-rata 493 (OECD, 2016). Tidak jauh berbeda dari hasil PISA, hasil survei Trends International Mathematics and Science Study (TIMSS) tahun 2015 memperlihatkan rendahnya prestasi pelajar Indonesia yang duduk di kelas VIII (delapan). Rata-rata skor siswa Indonesia hanya 397, 153 poin lebih rendah dibanding rata-rata prestasi belajar matematika seluruh negara yang mengikuti survei tersebut (IEA, 2016).

Whardani \& Rumiati (2011) menyatakan bahwa salah satu kemungkinan penyebab lemahnya siswa Indonesia dalam menyelesaikan soal-soal PISA dan TIMSS adalah siswa Indonesia masih mengalami kesulitan dalam mengaitkan matematika dengan disiplin ilmu lain dan kehidupan sehari-hari. Hal ini menunjukkan kemampuan koneksi matematis siswa Indonesia masih tergolong rendah. Kemampuan koneksi matematis merupakan salah satu kemampuan yang sangat penting dan harus dikuasi oleh siswa, karena matematika bukan merupakan himpunan subjek yang terpisah, tetapi memiliki keterkaitan dan terapan dalam kehidupan sehari-hari (NCTM, 2000). Hal ini sejalan dengan salah satu tujuan pembelajaran matematika yang tercantum dalam Kurikulum Tingkat Satuan Pendidikan (KTSP), yaitu agar peserta didik memiliki kemampuan memahami konsep matematika, menjelaskan keterkaitan antar konsep dan mengaplikasikan konsep atau algoritma, secara luwes, akurat, efisien dan tepat dalam pemecahan masalah (BSNP, 2006).

Menurut Sumarmo (2010), ketika belajar matematika siswa diharuskan dapat memahami keterkaitan antara ide-ide matematis dan antar matematika dan bidang studi lainnya karena topik-topik dalam matematika banyak memiliki relevansi dan manfaat dengan 
bidang lain, baik di sekolah maupun di luar sekolah. Siswa akan lebih mudah memahami setiap topik matematika, ketika siswa dapat menemukan koneksi antara ide-ide matematis.

Salah satu faktor yang mempengaruhi keberhasilan belajar siswa adalah cara guru memilih strategi, model atau pendekatan pembelajaran (Widdiharto, 2008). Hal ini didukung oleh hasil penelitian yang dilakukan oleh Yenni dan Komalasari (2016) yang menyatakan bahwa kurangnya variasi mengajar yang dilakukan oleh guru merupakan salah satu faktor penyebab lemahnya kemampuan matematis siswa. Oleh sebab itu, alternatif yang dapat dilakukan untuk meningkatkan hasil belajar matematika, khususnya kemampuan koneksi matematis siswa adalah dengan menggunakan strategi, model atau pendekatan pembelajaran yang dapat membantu pembuatan koneksi matematis siswa, salah satunya adalah pendekatan visual thinking. Thornton (2001) mengungkapkan bahwa visual thinking selalu menjadi bagian penting dari matematika. Visualisasi menyediakan pembuktian sederhana dan pendekatan yang mampu mengembangkan hasil belajar matematika, penyelesaian masalah dan proses pembuatan koneksi antar konsep matematika yang berbeda (Thorton, 2001). Visualialisasi dapat membantu pengembangan kemampuan berpikir kritis serta mengkonstruksi pemaknaan dan pemahaman. Seseorang dengan kemampuan berpkir kritis matematis dapat memahami koneksi logis antar ide, menidentifikasi, memberikan argumen dan memecahkan masalah secara sistematis (Makina, 2010). Visualisasi (dengan membuat diagram dan tabel) merupakan salah satu strategi yang dapat digunakan dalam pemecahan masalah (Krulik \& Posamentier, 2009). Seseorang dapat lebih mudah untuk memahami, menganalisis, memecahkan masalah serta memahami koneksi unsur-unsur yang terdapat dalam masalah dengan membuat representasi visual berupa diagram, sketsa, tabel dan gambar.

Zhukovskiy \& Pivovarov (2008) menyatakan bahwa visual thinking merupakan tipe pemikiran non-verbal dan telah diteliti secara luas oleh para psikolog. Para psikolog percaya bahwa fungsi utama visual thinking adalah kemampuannya untuk mengkoordinasi makna berbeda dari suatu gambaran menjadi gambar visibel yang utuh. Amheim (Zhukovskiy \& Pivovarov, 2009) menuliskan bahwa seseorang tidak dapat menyampaikan informasi kepada orang lain secara langsung tanpa mempresentasikan informasi tersebut ke dalam bentuk yang terstruktur dengan jelas.

Beberapa penelitian menggambarkan bahwa visual thinking dapat membantu keberhasilan belajar matematika. Penelitian yang melibatkan 193 siswa kelas 5 (lima) SD di 
Pahang menunjukkan bahwa pendekatan visual mampu meningkatkan pemahaman matematika siswa. Penelitian ini menunjukkan pentingnya membuat representasi visual dalam matematika, dengan representasi visual siswa mampu mengidentifikasi konsep dan prosedur yang diperlukan dalam menyelesaikan masalah (Abdullah, Zakaria \& Halim, 2012). Visual thinking mampu meningkatkan pemahaman geometris dan keterampilan spasial mahasiswa (Walker, et.al, 2011). Surya (2010) menyimpulkan bahwa visual thinking dapat memaksimalkan pembelajaran matematika serta membangun karakter bangsa.

Terdapat banyak teori mengenai pendekatan visual thinking. Pada penelitian ini langkah-langkah pendekatan visual thinking yang dikembangkan oleh Bolton. Adapun langkah-langkah pendekatan visual thinking menurut Bolton (2011) adalah : (1) Looking, pada tahap ini, siswa mengidentifikasi masalah dan hubungan timbal baliknya, merupakan aktivitas melihat dan mengumpulkan; (2) Seeing, memahami masalah dan tantangan, dengan aktivitas menyeleksi dan mengelompokkan; (3) Imagining, mengeneralisasikan langkah untuk menemukan solusi, kegiatan pengenalan pola; (4) Showing and Telling, menjelaskan apa yang dilihat dan diperoleh kemudian mengkomunikasikannya. Presmeg (Surya, 2011) menyatakan bahwa salah satu peranan visual thinking adalah untuk melihat keterkaitan masalah. Artinya, secara teori pendekatan visual thinking dapat dijadikan suatu alternatif pendekatan pembelajaran yang berpengaruh terhadap kemampuan untuk mengaitkan atau membuat koneksi. Penelitian ini bertujuan untuk melihat pengaruh pendekatan visual thinking terhadap kemampuan koneksi matematis siswa.

\section{METODE PENELITIAN}

Penelitian ini merupakan penelitian kuasi eksperimen dengan desain quasi eksperiment nonequivalen control group. Sampel penelitian adalah siswa kelas VIII MTs Negeri 094 Tembilahan Riau, tahun ajaran 2011-2012. Pemilihan sampel dilakukan dengan teknik purposive sampling. Penelitian dilakukan di dua kelas, yaitu kelas eksperimen yang diberikan perlakuan berupa pembelajaran dengan pendekatan visual thinking dan kelas kontrol yang memperoleh pembelajaran konvensional.

Instrumen yang digunakan dalam penelitian adalah instrumen tes dan nontes. Instrumen tes berupa tes kemampuan koneksi matematis yang berbentuk uraian yang penskorannya dilakukan berdasarkan quasar general rubric yang dinyatakan Lane (1993). Tes tertulis yang terdiri atas 3 (tiga) soal uraian diberikan dalam bentuk pretes dan postes. Pretes 
dilaksanakan di awal penelitian, sebelum perlakukan diberikan dan postes dilaksanakan setelah siswa memperoleh pembelajaran berupa pendekatan visual thinking. Instumen nontes yang digunakan adalah lembar observasi. Lembar observasi ini digunakan untuk melihat aktivitas siswa dan guru di setiap pertemuan.

Data peningkatan kemampuan koneksi matematis dihitung berdasarkan rumus gain ternormalisasi yang dikembangkan oleh Melzer (2002), yaitu:

Gain ternormalisasi $(\mathrm{g})=\frac{\text { skorpostes }- \text { skorpretes }}{\text { skorideal }- \text { skorpretes }}$

Hasil perhitungan gain ternormalisasi kemudian diinterpretasikan dengan menggunakan klasifikasi yang dinyatakan oleh Hake (1999) sebagaimana tabel 1 berikut:

Tabel 1. Klasifikasi Gain Ternormalisasi

\begin{tabular}{cc}
\hline Besarnya N-Gain $(\mathrm{g})$ & Interpretasi \\
\hline $\mathrm{g} \geq 0,7$ & Tinggi \\
$0,3 \leq \mathrm{g}<0,7$ & Sedang \\
$\mathrm{g}<0,3$ & Rendah \\
\hline
\end{tabular}

Data n-gain yang diperoleh selanjutnya diuji kenormalan dan homogenitasnya. Karena berdasarkan uji normalitas diketahui bahwa peningkatan kemampuan koneksi matematis baik kelas eksperimen maupun kelas kontrol berdistribusi tidak normal, maka n-gain dianalisis menggunakan uji nonparametrik U Mann-Whitney.

\section{HASIL DAN PEMBAHASAN}

Sebelum melakukan analisis inferensial terhadap data yang diperoleh dari penelitian, dilakukan analisis statistik deskriptif. Tabel 2 berikut memperlihatkan statistik deskriptif data pretes, postes dan peningkatan kemampuan koneksi matematis siswa.

Tabel 2. Statistik Deskriptif Kemampuan Koneksi Matematis Siswa

\begin{tabular}{clccccc}
\hline \multicolumn{2}{c}{ Kelas } & $\mathrm{N}$ & Max & Min & $\overline{\boldsymbol{x}}$ & $\mathrm{Sd}$ \\
\hline \multirow{6}{*}{ Eksperimen } & Pretes & 31 & 10 & 0 & 3,26 & 2,66 \\
& Postes & & 12 & 1 & 5,81 & 3,19 \\
& N-Gain & & 1,00 & $-0,40$ & 0,28 & 0,35 \\
& Pretes & 36 & 5 & 0 & 1,72 & 1,54 \\
& Postes & & 10 & 0 & 4,17 & 2,59 \\
& N-Gain & & 0,80 & -0.09 & 0,23 & 0,23 \\
\hline
\end{tabular}

Memperhatikan tabel 2, kita dapat melihat bahwa rata-rata peningkatkan kemampuan koneksi matematis siswa kelas eksperimen lebih besar 0,05 dibanding kelas kontrol. Namun, untuk melihat apakah peningkatan ini signifikan, maka kita harus melakukan pengujian lebih lanjut. Penyebaran data pretes, postes dan n-gain baik di kelas kontrol maupun kelas 
eksperimen terlihat hampir seimbang. Tabel 2 juga menunjukkan terdapat penurunan kemampuan koneksi matematis di kedua kelas.

Untuk melihat signifikansi peningkatan kemampuan koneksi matematis siswa, maka dilakukan ujinormalitas terlebih dahulu yang bertujuan untuk menentukan uji yang akan kita gunakan selanjutnya. Dari hasil uji normalitas terhadap data n-gain kelas eksperimen dan kelas kontrol memperlihatkan kedua data tersebut tidak berdistrisibusi normal. Karena tidak berdistrisibusi normal, maka dilakukan uji nonparametrik U Mann-Whitney. Hasil pengujian dapat dilihat dari tabel berikut:

\begin{tabular}{cc} 
Tabel 3. Hasil Uji U Mann-Whitney \\
\hline U Mann Whitney & 502,00 \\
\hline$Z$ & 1168,00 \\
$\operatorname{Sig}(2$ arah $)$ & 0,48 \\
\hline
\end{tabular}

Tabel 3 menunjukkan nilai signifikansi ( 2 arah) terhadap data peningkatan kemampuan koneksi matematis adalah 0,48. Menurut Uyanto (2009), nilai signifikansi (1 arah) sama dengan $\frac{1}{2}$ signifikansi ( 2 arah), jadi nilai signifikansi ( 1 arah) adalah 0,28. Nilai ini lebih besar dibanding taraf signifikansi $\alpha=0,05$, sehingga $H_{0}$ diterima. Artinya tidak terdapat perbedaan antara peningkatan kemampuan koneksi matematis siswa kelas eksperimen dan kelas kontrol.

Tujuan penelitian ini adalah melihat pengaruh pendekatan visual thinking terhadap peningkatan kemampuan koneksi matematis siswa. Hasil penelitian ini dapat dijadikan rujukan atau bahan pertimbangan dalam penggunaan variasi pendekatan pembelajaran matematika. Bagi guru, pendekatan visual thinking ini dapat menjadi alternatif pendekatan pembelajaran matematika.

Berdasarkan hasil penelitian dan analisis data diketahui bahwa tidak terdapat perbedaan antara peningkatan kelas eksperimen dan kelas kontrol. Hal ini menyatakan bahwa tidak terdapat pengaruh yang signifikan pendekatan visual thinking terhadap kemampuan koneksi matematis siswa. Kondisi ini tentunya tidak sesuai dengan tujuan yang diharapkan oleh peneliti. Tentunya, kondisi ini terjadi dikarenakan oleh beberapa faktor.

Penyebab rendahnya hasil pembelajaran dengan pendekatan visual thinking pada kemampuan koneksi matematis adalah tidak munculnya koneksi internal (koneksi antar konsep matematika) dalam aktivitas pembelajaran dengan pendekatan visual thinking. Hal ini diperparah dengan kurangnya penguasaan siswa terhadap materi prasyarat, khususnya mengenai sudut dan perubahan satuan. Sebagaimana disebutkan oleh Wahyudin (1999) bahwa 
kecenderungan siswa gagal menguasai dengan baik pokok bahasan geometri ruang di antaranya adalah siswa kurang menguasai dengan baik konsep-konsep dasar matematika serta siswa kurang memiliki penguasaan materi prasyarat dengan baik. Pernyataan ini didukung oleh Sagala (2005) bahwa keberhasilan peserta didik dalam pembelajaran diperlukan prasyarat tertentu diantaranya menguasai bahan-bahan dasar yang diperlukan untuk meneruskan pelajaran sekolah yang menjadi lanjutannya.

Kurangnya penguasaan konsep sudut terlihat saat proses belajar mengajar, yaitu ketika menggambar bangun dan melukis jaring-jaring bangun ruang sisi datar (pada pertemuan pertama), terutama bangun prisma dan limas. Siswa masih kesulitan menentukan sudut yang tepat agar diperoleh gambar dan jaring-jaring yang benar.

Berdasarkan hasil yang diperoleh dapat dikatakan bahwa pembelajaran dengan pendekatan visual thinking belum mampu meningkatkan kemampuan koneksi matematis. Perbedaan peningkatan kemampuan koneksi matematis siswa yang memperoleh pembelajaran dengan pendekatan visual thinking dan kelas dengan pembelajaran konvensional hanya 5,80 dari skor ideal maksimal 12. Artinya, pembelajaran yang dilakukan belum bisa dikatakan berhasil.

Kemungkinan penyebab ketidakberhasilan pembelajaran dengan pendekatan visual thinking adalah kurangnya soal-soal latihan yang diberikan karena terlalu fokus dalam kegiatan pembelajaran dan kurang bervariasinya soal-soal yang diberikan. Sebagaimana yang diungkapkan oleh Novitasari (2016) bahwa dalam pembelajaran matematika diperlukan variasi soal untuk meningkatkan pemahaman siswa terhadap suatu konsep. Pembelajaran dengan pendekatan visual thinking menyebabkan meningkatnya kecerobohan siswa dalam mengerjakan soal. Hal ini didukung oleh pernyataan Zahar (2009) bahwa berpikir visual dapat menyebabkan siswa kurang teliti, walaupun siswa tersebut pintar dalam matematika. Ketika mengerjakan soal-soal tes, siswa kurang mampu membaca soal yang diantaranya disebabkan oleh kurang teliti membaca soal, salah penafsiran. Faktor lainnya adalah tidak teliti dan ceroboh dalam perhitungan teknis (Wardhani \& Rumiati, 2011).

Selain itu, pencapaian yang masih rendah pada penelitian ini juga disebabkan oleh perlunya pembuktian perubahan yang gradual dan waktu bagi guru dan siswa. Dengan kata lain, perlu proses yang panjang dan pemahaman guru yang terintegrasi, dan hal ini tentunya memerlukan waktu dan usaha yang tidak dapat diperoleh secara instan. 


\section{KESIMPULAN}

Penelitian ini bertujuan untuk melihat pengaruh pendekatan visual thinking terhadap peningkatan kemampuan koneksi matematis siswa. Berdasarkan hasil penelitian dan analisis data menggunakan uji nonparametrik U Mann Whitney diperoleh kesimpulan bahwa tidak terdapat pengaruh pembelajaran dengan pendekatan visual thinking terhadap kemampuan koneksi matematis siswa.

\section{REKOMENDASI}

Sebelum mengimplementasikan pembelajaran dengan pendekatan visual thinking ini, maka sebaiknya guru mengecek kembali penguasan siswa terhadap materi prasyarat dari konsep matematika yang akan diajarkan, sehingga kompetensi matematis dapat dicapai secara maksimal. Dalam penerapan pembelajaran dengan pendekatan visual thinking, sebaiknya guru memberikan soal-soal latihan yang beragam dan yang bersifat non rutin, sehingga dapat memancing siswa untuk berpikir dan bernalar yang akhirnya mampu memeningkatkan kemampuan berpikir matematis tingkat tinggi siswa.

\section{REFERENSI}

Abdullah, N, Zakaria, E \& Halim, L. (2012). The Effect of Thinking Strategy Approach through Visual Representation on Achievement and Conceptual Understanding in Solving Mathematical Word Problem. Asian Social Science, 8(16).

Badan Standar Nasional Pendidikan. (2006). Panduan Pengembangan Silabus Kurikulum Tingkat Satuan Pendidikan (KTSP). Jakarta : CV. Laksana Mandiri.

Bolton, S. (2011). Decoding Visual Thinking. Naver Workshop, Visualising Creative Strategies. (Online), (http://issuu.com/gpbr/docs/decodingvisualthinking).

Hake, R.R. (1999). Analyzing Change/Gain Scores. (Online), (http://www.physics.indiana.edu/ sdi/Analyzingchange-Gain.pdf).

IEA. (2016). TIMSS 2015 International Result in Mathematics. (Online), (http://timss2015.org/wp-content/uploads/filebase/full\%20pdfs/T15-InternationalResults-in-Mathematics-Grade-4.pdf).

Krulik, S \& Posamentier, A. (2009). Problem Solving in Mathematics Grade 3-6. California: Corwin A SAGE Company. 
Lane (1993). The Conceptual Framework for the Development of a Mathematics Performance Assessment Instrument. Educational Measurement: Issues and Practice. (Online), (http://web.njit.edu/ ronkowit/teaching/rubrics/samples/math_probsolv_chicago.pdf).

Makina, A. (2010). The Role of Visualisation in Develoving Critical Thinking in Mathematics. Perspectives in Education, 28(1).

Meltzer, D.E. (2002). The Relationship between Mathematics Preparation and Conceptual Learning Gains in Physics: A Possible "Hidden Variable" in Diagnostic Pretest Scores. Iowa: Department of Physics and Astronomy.

National Council of Teachers of Mathematics. (2000). Principles and Standard for School Mathematics. Reston: NCTM.

Novitasari, D. (2016). Pengaruh Penggunaan Multimedia Interaktif terhadap Kemampuan Pemahaman Konsep Matematis Siswa. Jurnal Fibonacci: Jurnal Pendidikan Matematika dan Matematika, 2(2), 8-18.

OECD. (2016). PISA 2015 Result in Focus. (Online), (http://www.pisa.oecd.org/).

Sagala, S. (2005). Konsep dan Makna Pembelajaran. Bandung: Alfabeta.

Sumarmo, U. (2010). Berpikir dan Disposisi Matematik: Apa, Mengapa dan Bagaimana Dikembangkan pada Peserta Didik. Makalah Tidak Diterbitkan. Bandung: Universitas Pendidikan Indonesia.

Surya, E. (2010). Visual Thinking dalam Memaksimalkan Pembelajaran Matematika Siswa dapat Membangun Karakter Bangsa. Jurnal Abmas, 10(10). (Online), (http://jurnal.upi.edu/abmas).

Thornton, S. (2001). A Picture is Worth A Thousand Words. (Online), (http://math.unipa.it/ grim/AThornton251.PDF).

Whardani, Sri \& Rumiati. (2011). Instrumen Penilaian Hasil Belajar Matematika SMP: Belajar dari PISA dan TIMSS. Yogyakarta: Pusat Pengembangan dan Pemberdayaan Pendidik dan Tenaga Kependidikan Matematika.

Widdiharto, R. (2008). Diagnosis Kesulitan Belajar Siswa SMP dan Alternatif Proses Remedinya. Yogyakarta: PPPPTK.

Wahyudin. (1999). Kemampuan Guru Matematika, Calon Guru Matematika dan Siswa dalam Mata Pelajaran Matematika. Disertasi Tidak diterbitkan. Bandung. Universitas Pendidikan Indonesia.

Walker, C.M, Winner, L, Hetland, L, Simmons, S \& Goldsmith, L. (2011). Visual Thinking: Art Students Have an Advantage in Geometry Reasoning. Creative Education, 2(1). DOI : $10.4236 /$ ce.2011.21004. 
Yenni, Y. (2016). Pengaruh Model Pembelajaran Learning Cycle Terhadap Kemampuan Pemahaman dan Koneksi Matematis Siswa SMP. KALAMATIKA Jurnal Pendidikan Matematika, 1(1), 71-83.

Zahar, I. (2009). Belajar Matematikaku: Pembelajaran Matematika secara Visual dan Kinestetik. Jakarta : Elex Media Komputindo.

Zhukovskiy, V.I \& Pivovarov, D.V. (2008). The Nature of Visual Thinking. Journal of Serebian Federal University. (Online), (http://journal.sfu-kras.ru/en/article/641/25).

Zhukovskiy, V.I \& Pivovarov, D.V. (2009). European Journal of Natural History. Characteristics of Visual Thinking. (Online), (http://www.world-science.ru/euro/12620480). 